\title{
Communication Styles used by Effective EFL Teachers in Classroom Interaction
}

\author{
Suharni \\ suharni2227@gmail.com \\ Haryanto Atmowardoyo \\ aharyanto_fbsunm@yahoo.co.idharyanto@unm.ac.id \\ Kisman Salija \\ kismansalija-@unm.ac.id \\ State University of Makassar, Indonesia

\begin{abstract}
This research was conducted to find out; (1) the characteristics of the effective teachers based on the students' perception; (2) to describe the communication styles used by EFL teachers in classroom interaction; (3) to find out when and why the teacher used the aggressive, assertive and passive style. This research applied mixed method research. The instruments of this research were questionnaire, observation, and interview. The sample of this research consisted of 265 students at SMA Ummul Mukminin boarding school Makassar, in academic 2017/2018. The subjects of the research were three experienced English teachers. The research finding based on students' perception to the EFL English teachers in each class showed that Mrs. Wal got 73.5\% categorized as very effective teacher, Ms. WN got $76.9 \%$ categorized as very effective teacher, Mr. As got $65.2 \%$ categorized as effective teacher. The teacher was very effective described by students who had 20 positive attitudes that have to be done and 24 negative attitudes for ineffective teachers that must be avoided. Furthermore, the research revealed three findings in communication styles used by teachers. The first was aggressive style, the second was assertive style, and the third was passive style. The teachers used those styles based on the context and situation during English classroom process. The most dominant communication style used by the teacher was aggressive.
\end{abstract}

Field Code Changed

Key words: students' perception, characteristics of the effective teachers, communication styles

\section{INTRODUCTION}

Communication in the classroom is one of the complicated phenomena in education fields and it is as the central of classroom activities. The teacher had important roles in the success and the failure of teaching and learning process. Teacher should interact as a communicative as possible in order to make the students understand 
what the teacher is talking about. Yunus (2013:1) states that professional teachers/lecturers need to be equipped with the ability to present themselves as well as cognitive ability. Present themselves in question means the lecturer should have an ability to create a favorable atmosphere through their communication style because it takes the important roles in the classroom.

Referring to the importance of communication in the classroom, the teacher or lecturer is involved because a teacher or lecturer is required to create the best learning environment in the classroom interaction by communicating well in the process of teaching and learning. Teaching in the classroom is not merely the process of teaching but it is also the reflection of teacher's communication that is determined to their teaching goals to the students. The relationship between teacher and students in the classroom can create positive classroom environment when there is a supportive relationship between them. Because it can offer the chances to students to be motivated and feel engaged in improving the learning process.

This intrigued the researcher to find out what styles of communication are used by the teachers or lecturer in classroom interaction. The result of this study expected that teacher or lecturer could apply the styles of communication based on the context and situation in order to make their students understand about teachers' explanation.

| This research was conducted at UMMUL MUKMININ School in academic year 2017/2018 during the teaching and learning process of EFL classroom. Some of the reasons why this school was chosen as the place of the research, it was based on the view of society that SMA Ummul Mukminin boarding school has not only a good moral education, but also has superior in mastery of Arabic and English. It can be seen that the school involved in activities that brings good name get champions in every language competition. Besides, many of the students come from several districts of Makassar and some come from other provinces from all over the island of Indonesia. With this phenomenon, parents certainly hope for their children to learn at SMA UMMUL MUKMININ to gain Islamic knowledge and also the general knowledge especially in language, because by mastering many languages, especially the International language namely Arabic and English, we could know the world news accurately.

The second phenomenon was the use of bilingual in this school such as Arabic and English goes well. It can be seen when students talk to each other outside of classroom interaction activities and when announcing about some information and also on lecture or speech practice. The researchers are interested to see and to know what communication styles were applied by English teachers especially in classroom interactions. 
Based on the phenomenon above, the researcher interested to build up the research about "communication styles used by the effective EFL teachers in classroom interaction " which was conducted at UMMUL MUKMININ Boarding School, in academic year 2017/2018.

\section{LITERATURE REVIEW}

Hanif, et al. (2012) conducted research entitled "Communication style of employed and unemployed men and women in Pakistan" in this research they had investigated about whether the young employed and unemployed man and woman in Pakistan have different communication style and what the predominant style of each is. They also compared the communication style of employed and unemployed man and woman. In this research they used Norton's communication style measurement questionnaire in collecting the data. In addition, they focused on several types of communication such: animated, attentive, contentious/argumentative, dominant, dramatic, friendly, impression leaving, open and relaxed. As the conclusions of this research, they found that from the categories of the subject, they are equally used the dominant styles in their communication. And then, in this research they also have found that unemployed woman are more precise in their communication style than employed woman.

Markova (2011), in his research entitled "The Japanese communication style". In this research, she analyzed about the Japanese communication style. This research aims to explain about the Japanese communication style from the perspectives of Slovak students and to explain A non-Western view of Japanese communication style. Furthermore, this research is expected to give understanding for readers about how to understand the Japanese style in their communication in order that we can be more sensitive toward the differences in our communication, and as the result of this research the researcher found that Japanese are not as purpose oriented but as relationship oriented when they are communicating.

Another group of related research was conducted by Yunus (2003), a lecturer of Study Program of Marketing Communication at Bina Nusantara University in Indonesia. This research focused on an observation about how close relationship between credibility, attraction and power of lecturer with the healthy behavioral in the classroom. In this research Yunus (2003) applied explanatory survey about ethos communicator (lecturer of Institute of Technology and Business in Kaibe Jakarta), and in testing the data the researcher used SPSS Program. The result of this research can be concluded that professional lecturers need to be equipped with the ability to present themselves as well as cognitive 
Berson (2013), in his research 'The effects of supervisors' communication styles on interns' satisfaction and learning". On her research she tried to investigate how the supervisors' communication style related to important outcomes for interns namely, their satisfaction and learning. The result of this study showed that supervisors employed the collaborative communication style significantly more often than the authoritarian communication style.

Lanz (2015) under the title "critical analysis of management communication style". The purpose of this research is to explain the effects of management communication styles on the employee and how it affects their behavior and attitude. He analyzed the style of communication based on three basics of communication styles, they are passive, aggressive and assertive style.

\section{METHOD}

\section{Design and Sample}

The aims of this research were to find out the characteristics of effective EFL teachers based on students' perception, to describe the style of communication used by effective EFL teachers in classroom interaction, and to find out when and why the teacher used aggressive, assertive and passive style. This research was conducted by using mixed method. The sampling technique used was purposive sampling technique. Subjects of the research were three teachers of SMA Ummul Mukminin boarding school Makassar. The respondents determined the characteristics of effective EFL teachers by scoring the questionnaire. The respondents consisted of 265 students in the first, second and third grade of senior high school.

\section{Instruments and procedures}

This research used three kinds of instruments, they are questionnaire, observation and interview. Questionnaires were used for preliminary data to identify the characteristics of the effective EFL teachers based on the students' perception. The researchers applied the Liker scale according to Atmowardoyo H., et.al (2017) . Questionnaires involved 265 students at senior high school of Ummul Mukminin Boarding School Makassar. The researchers conducted observation in six meetings by recording teachers' utterances. After doing the observations, the researchers interviewed the teachers to find out the deeper information about the style of communication used by EFL teacher in classroom interaction. The researchers used audio recorder to fit the data which was described by the participants during the observation and interview. The researchers used the semi-structured interview. To check the strength of the data, the researchers used data triangulation based on 
Miles and Huberman's (1994). The data were analyzed through data reduction, data display, and conclusion.

\section{Data Analysis}

1. Calculating questionnaire

The data of questionnaire was analyzed by using Liker scale, it is according to Atmowardoyo H. et al. (2017). The respondents chose and circled number 1.2.3 or 4 to respond 44 statements of characteristics of the effective EFL teachers. Score 1 meant "strongly disagree"; score 2 meant "disagree"; score 3 meant "agree", or score 4 meant "strongly agree". Each response had its own value. The questionnaires consisted of 20 positive statements (PS); and 24 negative statements (NS). For PS, the scores $1=1 ; 2=2 ; 3=3 ; 4=4$. For NS, the scores $1=4 ; 2=3 ; 3=2$; $4=1$. Both scores would be summed and would be ranged from $44-176$. Then the sum would be divided by 2 to obtain the final score. The final score will range from 22 to 88. Example: Teacher A got PS 60 and NS 70. The final score was $60+70=$ $130 / 2=65$ (effective). The interval of categories of students' perception regarding an effective teacher is showed below:

$2-88=$ very effective

$5-71=$ effective

$8-54=$ ineffective

$2-37=$ very ineffective

\section{Data Analysis}

In analyzing data from classroom observation and interview, the researcher used data triangulation in analysis the data, it was based on Miles \& Huberman's, (1994) which consisted of three steps of activities: data reduction, data display, and conclusion drawing/ verification.

a. Data reduction

Data reduction is the process where the researcher identified, simplified and transformed the raw data. The raw data obtained from observations and interviews through recording and transcribed it into qualitative data. Then it was coded and categorized according to the most important part which is relevant to the characteristic of communication styles. Therefore, the analysis will focus into the data which is suitable to the questions statement which has been formulated.

\section{b. Data Display}

After reducing the data, the next step was displaying the data. The display means a group of information that leads the researcher to draw the conclusion. The data 
display shown was based on the research focus. By displaying the data, it can be seen from the data that have been reduced or taken.

c. Conclusion or verification

The last step in this process was conclusion or verification. The researcher made conclusion based on the data display like the new theory and it also answered the questions of the research. The researcher concluded the types of communication style used by the teacher and communication style most dominantly used by the teacher in EFL classroom interaction.

\section{RESULTS AND DISCUSSION}

\section{Students' perception on the characteristics of the effective EFL teachers}

The findings of the research dealt with the students' perception on the characteristics of an effective EFL teacher, they consisted of 22 are positive statements and 24 are negative statements. The following are positive characteristics of the effective EFL teachers:

1. using English well and fluently, writes correctly, and masters the English grammar well

2. performing innovative and varied learning

3. using clear learning steps

4. knowing the student's learning needs and knew how to recognize the student's abilities

5. delivering the material clearly, simply, and systematically

6. providing speaking and writing exercises in English

7. having a way of teaching is accompanied by ice breakers and jokes

8. being always motivates students in every lesson to be always enthusiastic, including encouraging students to be able to memorize new words and use them in conversation

9. looking cheerful and smiling easily

10. using electronic media in the form of movies or song in learning

11. making the class interactive and familiar atmosphere

12. providing examples, appropriate solutions, and appropriate feedback on students' questions

13. can assign tasks to students in creative and imaginative forms such as making dramas, poetry, etc.

14. fair in scoring and providing feedback on the students' work

15. well-dress, and looks handsome/beautiful

16. showing positive attitudes, wisdoms, funs and affections to students

17. can control emotions at time s that are not fun

18. showing a cheerful attitude

19. exhibiting an attitude that can be emulated by the students 


\section{0. having high dedication}

Based on the result of questionnaire to students, in order to pick up one of the three teachers, the researcher determined the most effective teacher. The respondents assessed the English teacher related to the criteria stated on the questionnaire. Then respondents chose the best score for teachers who characterized the criteria of effective EFL teachers. The final score was obtained by summing and counting the number which marked or chosen by the participants of the assessed teacher. The result of the effective teachers based on students' perception is showed in the table below:

Table 1 Results of Questionnaire to Students

\begin{tabular}{|c|c|c|c|}
\hline Teacher & Participants & Score (PS + NS) & Final Score \\
\hline Mrs. Wal & 81 & 146.9 & 73.5 \\
\hline Ms. WN & 85 & 153.8 & 76.9 \\
\hline Mr. AS & 90 & 130.4 & 65.2 \\
\hline
\end{tabular}

Table 1 is based on the students' assessment showed that all of the EFL teachers were in very effective and effective category. From the score, it showed that Mrs. Wal got 73.5, and Ms. WN's score was 76.9, therefore they are categorized as very effective teacher. While Mr. AS got 65.2 and categorized as effective teacher. Then, the data were presented for communication styles that are used by the English teachers. The teacher whom categorized as very effective and had the highest score became the subject of the research to be analyzed.

\section{The communication styles are used by effective EFL teachers}

From the class observation through transcribing data of audio recorder, the researcher found three styles of communication that were used by the teacher in classroom interaction from the first meeting until the sixth meeting. Those types of teachers' communication styles were aggressive, assertive, and passive. The extracts were taken in different class, different time and different topics.

Table 2 Data Display of the aggressive style

\begin{tabular}{|l|l|l|l|}
\hline \multicolumn{1}{|c|}{ Utterance } & $\begin{array}{c}\text { Communication } \\
\text { Style }\end{array}$ & \multicolumn{1}{|c|}{ Characteristics } & $\begin{array}{l}\text { Communication } \\
\text { Purposes }\end{array}$ \\
\hline $\begin{array}{l}\text { "what is the title?" } \\
\text { okey, Hold on a moment } \\
\text { please!" }\end{array}$ & Aggressive & $\begin{array}{l}\text { She used loud } \\
\text { intonation, spoke } \\
\text { fluently without } \\
\text { hesitation and } \\
\text { repeated her words } \\
\text { three times. }\end{array}$ & $\begin{array}{l}\text { She started the } \\
\text { lesson and } \\
\text { called } \\
\text { students' } \\
\text { attention. }\end{array}$ \\
\hline
\end{tabular}


ELT Worldwide Vol 5 No 2 (2018)

Suharni, Atmowardoyo, Salija : Communication Style used by ...

\begin{tabular}{|c|c|c|c|}
\hline 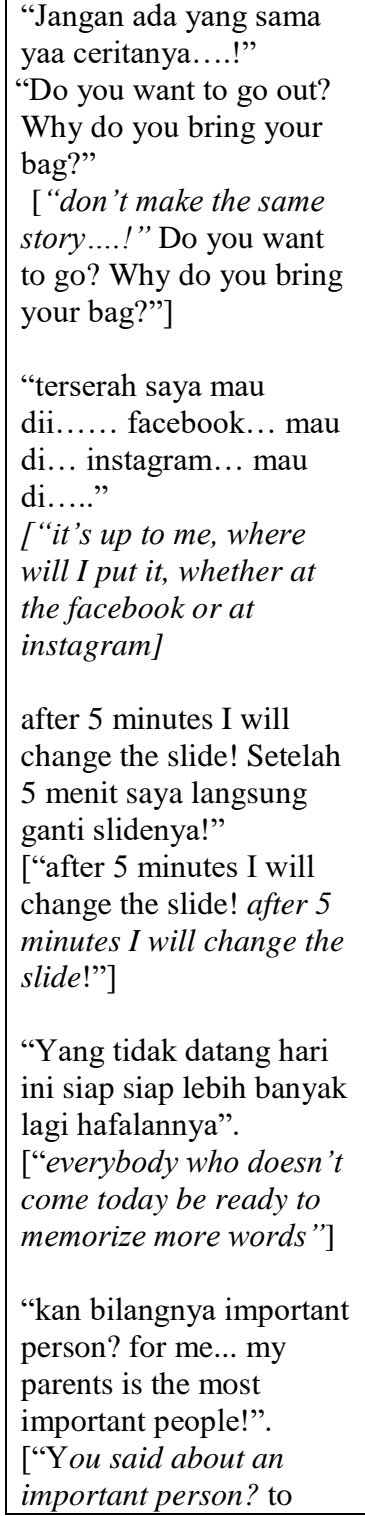 & Aggressive & $\begin{array}{l}\text { Tone often fast and } \\
\text { firm voice, it also } \\
\text { seemed that she } \\
\text { was bullying } \\
\text { someone. } \\
\text { She used racist } \\
\text { remarks. }\end{array}$ & $\begin{array}{l}\text { Gave the } \\
\text { feedback by } \\
\text { comparing the } \\
\text { students' } \\
\text { answer }\end{array}$ \\
\hline
\end{tabular}


ELT Worldwide Vol 5 No 2 (2018)

Suharni, Atmowardoyo, Salija : Communication Style used by ...

\begin{tabular}{|c|c|c|c|}
\hline $\begin{array}{l}\text { me... my parents is the } \\
\text { most important } \\
\text { people!".] } \\
\text { "Do you want to add? } \\
\text { After that you memorize } \\
\text { it". }\end{array}$ & Aggressive & $\begin{array}{l}\text { She used } \\
\text { threatening } \\
\text { questions. }\end{array}$ & $\begin{array}{l}\text { Offered } \\
\text { students to } \\
\text { memorize } \\
\text { more } \\
\text { vocabularies }\end{array}$ \\
\hline
\end{tabular}

Table 3 Data Display of the assertive style

\begin{tabular}{|c|c|c|c|}
\hline Utterance & $\begin{array}{c}\text { Communication } \\
\text { Style }\end{array}$ & Characteristics & $\begin{array}{c}\text { Communication } \\
\text { Purposes }\end{array}$ \\
\hline $\begin{array}{l}\text { "nah kalo menurut } \\
\text { kalian dua-duanya } \\
\text { salah... perbaikannya } \\
\text { apa?" } \\
\text { [if you think both of } \\
\text { them are wrong... } \\
\text { what is the correction] }\end{array}$ & Assertive & $\begin{array}{l}\text { she used co- } \\
\text { operative } \\
\text { phrases. }\end{array}$ & $\begin{array}{l}\text { Asked a student } \\
\text { to explore her } \\
\text { opinion. }\end{array}$ \\
\hline $\begin{array}{l}\text { "very good.!" to gain } \\
\text { mutual advantages or } \\
\text { to get" Gain itu sama } \\
\text { dengan get, .. get } \\
\text { mutual advantages". } \\
\text { ["very good.!" to gain } \\
\text { mutual advantages or } \\
\text { to get" Gain is the }\end{array}$ & Assertive & $\begin{array}{l}\text { Gave good } \\
\text { response, } \\
\text { sincerely and } \\
\text { repeated other } \\
\text { words. }\end{array}$ & Gave response. \\
\hline $\begin{array}{l}\text { same with get, .. get } \\
\text { mutual advantages".] } \\
\text { " Ada berapa } \\
\text { dialogue? What will } \\
\text { you do with the } \\
\text { dialogues?". } \\
\text { "Okey.. arrange in a } \\
\text { good order.." } \\
\text { "Bisa kelihatan? } \\
\text { "yang lainnya... ini } \\
\text { ada bukunya?" } \\
\text { ['how many dialogues } \\
\text { are there? "Okay.. } \\
\text { arrange it in a good }\end{array}$ & Assertive & $\begin{array}{l}\text { Communicated } \\
\text { clearly and } \\
\text { sincerely, and } \\
\text { showed caring. }\end{array}$ & $\begin{array}{l}\text { Checked } \\
\text { students' } \\
\text { understanding. }\end{array}$ \\
\hline
\end{tabular}


ELT Worldwide Vol 5 No 2 (2018)

Suharni, Atmowardoyo, Salija : Communication Style used by ...

\begin{tabular}{|c|c|c|c|}
\hline $\begin{array}{l}\text { order.." can you see } \\
\text { it? The others.... Do } \\
\text { you have a book?”] } \\
\text { "is it enough?" } \\
\text { "okey, I will give } \\
\text { you... twenty } \\
\text { minutes". } \\
\text { "Okey, very good! } \\
\text { Kalo begini jan moko } \\
\text { bawa buku nah.. ku } \\
\text { jelaskan saja langsung } \\
\text { ko hafal.... Bagus too } \\
\text { sudah langsung } \\
\text { tersimpan". } \\
\text { ["okay, very good! } \\
\text { Furthermore you } \\
\text { don't need to bring a } \\
\text { book. I just explained } \\
\text { and you can memorize } \\
\text { it directly. wonderful, } \\
\text { it saved } \\
\text { automatically"] }\end{array}$ & Assertive & $\begin{array}{l}\text { She used } \\
\text { accepting } \\
\text { compliments } \\
\text { Good response, } \\
\text { honest, } \\
\text { communicated } \\
\text { clearly and } \\
\text { sincerely. }\end{array}$ & $\begin{array}{l}\text { Asked the } \\
\text { students to do the } \\
\text { assignment based } \\
\text { on the time. } \\
\text { The teacher } \\
\text { reviewed the } \\
\text { lesson. }\end{array}$ \\
\hline
\end{tabular}

Table 4 Data Display of the passive style

\begin{tabular}{|c|c|c|c|}
\hline Utterance & $\begin{array}{c}\text { Communication } \\
\text { Style }\end{array}$ & Characteristics & $\begin{array}{c}\text { Communication } \\
\text { Purposes }\end{array}$ \\
\hline $\begin{array}{l}\text { "Kira-kira kalo kita } \\
\text { berbicara di telepon itu } \\
\text { dipakai tidak?". } \\
\text { "Kira-kira itu bisa?". } \\
\text { ["Do you think it may } \\
\text { be used when we talk } \\
\text { on the phone? ". may it } \\
\text { be used?] }\end{array}$ & Passive & $\begin{array}{l}\text { Filled in words } \\
\text { may be. }\end{array}$ & $\begin{array}{l}\text { Checked students' } \\
\text { understanding }\end{array}$ \\
\hline $\begin{array}{l}\text { "boleh cess... } \\
\text { ambilkan dulu itu ee" } \\
\text { atau "tolong ambilkan } \\
\text { dulu itu!" }\end{array}$ & Passive & $\begin{array}{l}\text { Tone may be } \\
\text { sing-song or } \\
\text { whining. }\end{array}$ & $\begin{array}{l}\text { Explained the } \\
\text { lesson by giving } \\
\text { an example. }\end{array}$ \\
\hline
\end{tabular}


ELT Worldwide Vol 5 No 2 (2018)

Suharni, Atmowardoyo, Salija : Communication Style used by ...

\begin{tabular}{|c|c|c|c|}
\hline 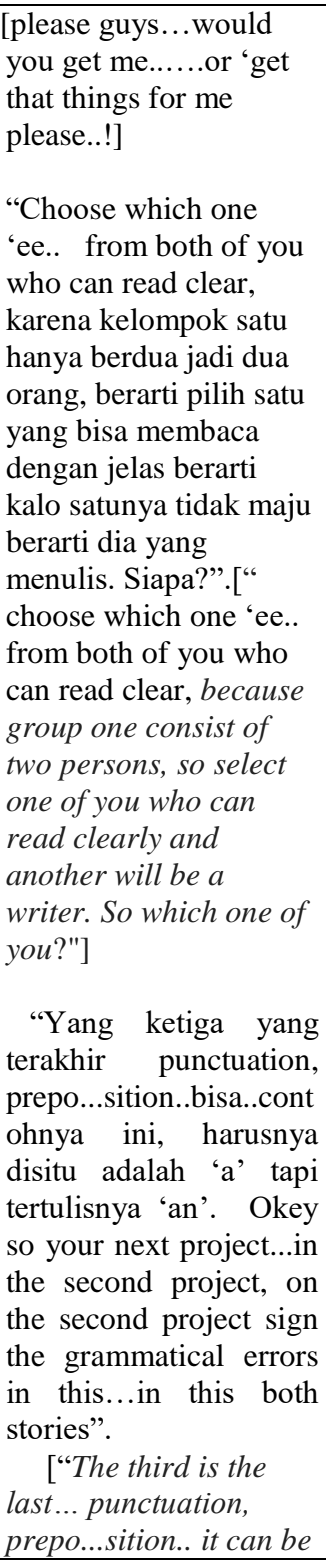 & Passive & $\begin{array}{l}\text { Teacher used } \\
\text { the frequent } \\
\text { justification. }\end{array}$ & $\begin{array}{l}\text { Asked students to } \\
\text { read aloud. }\end{array}$ \\
\hline
\end{tabular}




\begin{tabular}{|c|c|c|c|}
\hline $\begin{array}{l}\text {.. for example, it should } \\
\text { be there is 'a' but } \\
\text { written 'an'. Okay so } \\
\text { your next project...in } \\
\text { the second project, on } \\
\text { the second project sign } \\
\text { the grammatical errors } \\
\text { in this...in this both } \\
\text { stories"] } \\
\text { 17. "Arrange...Arrange } \\
\text { the sentence. The same } \\
\text { like last week, right? } \\
\text { Sama dengan minggu } \\
\text { lalu kan? diatur } \\
\text { kalimatnya. sesuaikan } \\
\text { Kira-kira kalimatnya } \\
\text { Susi yang pertama apa, } \\
\text { kemudian responnya } \\
\text { Linda seperti apa?" } \\
\text { [Arrange...Arrange the } \\
\text { sentence. The same like } \\
\text { last week, right? Same } \\
\text { with last week right? } \\
\text { arranged sentence. } \\
\text { Customize what the first } \\
\text { sentence from Susi, then } \\
\text { what Linda's } \\
\text { response?] }\end{array}$ & Passive & $\begin{array}{l}\text { Voice is often } \\
\text { dull and } \\
\text { monotonous }\end{array}$ & Give instruction \\
\hline
\end{tabular}

To know the frequent communication styles, the researcher calculated the frequency of characteristics of communication styles used by the teacher. The data were collected by audio recording from teacher's utterances in six meetings. After recording, the researcher transcribed the data. Then the researcher coded and analyzed the result of transcript data. Next, the researcher classified the data into characteristics of communication styles such as the aggressive, the assertive, and the passive style. After classifying the data, the researcher calculated the number of utterances at each meeting and then categorized it based on the communication style that was used by the teacher. Furthermore, the researcher summed up the total style of aggressive, assertive and passive in each meeting. As the result the researcher determined what was the mostly communication styles mostly used by the teacher and it can be seen in the table below. 
ELT Worldwide Vol 5 No 2 (2018)

Suharni, Atmowardoyo, Salija : Communication Style used by ...

Table 5 Frequency of Communication Styles Used by the teacher

\begin{tabular}{|c|c|c|c|c|}
\hline Meeting & $\begin{array}{c}\text { Aggressive } \\
\text { style }\end{array}$ & Assertive style & $\begin{array}{c}\text { Passive } \\
\text { style }\end{array}$ & Total \\
\hline $1^{\text {st }}$ meeting & 51 & 41 & 13 & 105 \\
\hline $2^{\text {nd }}$ meeting & 49 & 43 & 11 & 103 \\
\hline $3^{\text {rd }}$ meeting & 41 & 28 & 8 & 77 \\
\hline $4^{\text {th }}$ meeting & 38 & 51 & 11 & 100 \\
\hline $5^{\text {th }}$ meeting & 32 & 14 & 6 & 52 \\
\hline $6^{\text {th }}$ meeting & 51 & 25 & 9 & 85 \\
\hline Average & 43.7 & 33.7 & 9.7 & 522 \\
\hline
\end{tabular}

Table 5 represents the data about frequency of communication styles used by the teacher from the first until the sixth meeting. From the classroom recordings in six meetings the data indicated that the most dominant communication style used by the effective teacher in EFL classroom was aggressive where from 522 utterances, aggressive style occurred 262 times $(43.7 \%)$. The next followed by an assertive style; it occurred 202 times $(33.7 \%)$, and the last communication style was passive style. Based on the data observation, it occurred 58 times $(9.7 \%)$.

\section{When and why the effective EFL teachers use the aggressive, the assertive, and the passive style}

The first communication style used by the teacher in English classroom interaction was an aggressive style, it can be seen when she began the class and drew students' attention. This style was also used when the teacher gave the instruction, and advice, asked the students to do the assignment on time, and also asked the students to come earlier to the class. The teacher used this style in order to forbid and to remind her students. The teacher often said these utterances with firm voice, fast, and she spoke fluently.

The second communication style used by the teacher was the assertive. The style can be found when the teacher gave the explanation, clarified the best answer, gave suggestion, and responded the students' answer. The teacher used this style in order to motivate the students. 
The third communication style used by the teacher was the passive style. It was used by the teacher when she checked and asked about students' understanding. The teacher also used this style to drew students' attention while she was delivering the materials. This style was used by the teacher in order to ask for help. In saying the utterances, her tone may be sing-song or whining, over soft and warm, and she spoke slowly.

\section{CONCLUSION AND SUGGESTION}

\section{CONCLUSION}

Students at SMA Ummul Mukminin boarding school Makassar believe that teachers should reveal 20 of positive statements from 44 characteristics of the effective teachers. Very effective teachers described by students who used English well and fluently, writes correctly, and masters the English grammar well, performs innovative and varied learning, knows the student's learning needs and knows how to recognize the student's abilities, delivers the material clearly, simply, and systematically, provides speaking and writing exercises in English, their way of teaching is accompanied by ice breakers and jokes, always motivates students in every lesson to be always enthusiastic, including encouraging students to be able to memorize new words and use them in conversation, seemed cheerful and easily smiles, used electronic media in the form of movies or song in learning, always makes the class interactive and familiar atmosphere, provides examples, appropriate solutions, and appropriate feedback on students' questions, assigns tasks to students in creative and imaginative forms such as making dramas, poetry, etc., fairs in scoring and provides feedback on students' work, well-dressed, and looks handsome/beautiful, shows positive attitudes, wisdoms, funs and affections to students, can control emotions at time s that are not fun, shows a cheerful attitude, exhibits an attitude that can be emulated by the students, has high dedication, does not teach in a hurry.

The communication styles used by the teacher are aggressive, assertive, and passive style. The most dominant communication style used by the teacher was aggressive style. The aggressive was used when the teacher forbade and reminded the students. Assertive style was used when she motivated the students, and passive style was used when she asked for help.

\section{SUGGESTION}

Based on the conclusion above, the researchers would like to propose some suggestion as follows: 
For the teachers, it is suggested that they should pay attention to 44 characteristics of effective teachers as they are recommended by the students. It is also advisable for English teachers to use the three style of communication during the classroom interaction in order they can affect the students in receiving the English subject. Since this research only identified the styles of communication and when or why the teacher used it, it is suggested for further research to find out whether the teacher should know about the students' characteristics, the effects of the styles for students in teaching learning process and how they apply the styles of communication based on students' expectation. A further researcher could employ and analyze the different data of non-verbal communication styles used by English teacher in specific situation.

\section{REFERENCES}

Adams, C. M., Adams, C., Pierce, R. L., \& Pierce, R. (2006). Characteristics of Effective Teaching. Available on (http://www.lingofest.com/...). Retrieved on February, $19^{\text {th }} 2016$

Arikan, A., Taser, D. \& Sarac-Suzer, H. Sezgi. 2008. The effective English Language Teacher from the perspectives of Turkish Preparatory School Students. Education and Science 2008, Vol. 33 No. 150

(http://egitimvebilim.ted.org.tr/index.php/EB/article/download/629/99, accessed on January $22^{\text {nd }} 2013$ )

Atmowardoyo H, Ja'faruddin, Khaerati. 2017. Developing an Assessment Instrument for Indonesian EFL Teachers' Performance Based on the Students' Perceptions. vol. 6 issue 7 International Journal of Science and Research (IJSR). ISSN online: 2319-7064

Aydin Parim, G., \& Sözen Şahiner, D. (2013). Communication Styles Teachers Use In Numerical Lessons.

Bogdan, R. C., \& Biklen, S. K. (1992). Qualitative research: An introduction to theory and methods. Needham Height: Allyn \& Bacon.

Chen, Y.J \& Lin, S.C. 2009. Exploring Characteristics for Effective EFL Teachers from the Perceptions of Junior High School Students in Tainan. STUT Journal of Humanities and Social Science November 2009, No.2 pp. 219249. (http://society.stust.edu.tw/Sysid/society/files.pdf, accessed on January $22^{\text {nd. }}$ 2013) 
112 ELT Worldwide Vol 5 No 2 (2018)

Suharni, Atmowardoyo, Salija : Communication Style used by ...

Giri, V. N. (2006). Culture and communication style. The Review of Communication, 6(1-2), 124-130.

Mahmud M. (2017). Communicative Style of English Students at the State University of Makassar. GEMA Online Journal of Language Studies. 17(1), 223-238 